4 Jarvis MJ, Feyerabend C, Bryant A, Hedges B, Primatesta P. Passive smoking in the home: plasma cotinine concentrations in non-smokers with smoking partners. Tob Control 2001:10:368-74.

5 Jarvis MJ, Foulds J, Feyerabend C. Exposure to passive smoking among bar staff. Br J Addict 1992;87:111-3.

6 Jarvis M, Tunstall-Pedoe H, Feyerabend C, Vesey C, Salloojee Y. Biochemical markers of smoke absorption and self reported exposure to passive smoking. J Epidemiol Community Health 1984;38:335-9.

7 Tunstall-Pedoe H, Brown CA, Woodward M, Tavendale R. Passive smoking by self report and serum cotinine and the prevalence of respiratory and coronary heart disease in the Scottish heart health study. J Epidemiol Community Health 1995;49:139-43.

8 Walker M, Shaper AG, Lennon L, Whincup PH. Twenty year follow-up of a cohort based in general practices in 24 British towns. J Public Health Med a cohort based in

9 Feyerabend C, Russell MA. A rapid gas-liquid chromatographic method for the determination of cotinine and nicotine in biological fluids. $J$ Pharm Pharmacol 1990;42:450-2
10 Jarvis MJ, Tunstall-Pedoe H, Feyerabend C, Vesey C, Saloojee Y. Comparison of tests used to distinguish smokers from nonsmokers. Am J Public Health 1987:77:1435-8.

11 Jarvis MJ, Goddard E, Higgins V, Feyerabend C, Bryant A, Cook DG. Children's exposure to passive smoking in England since the 1980s: cotinine evidence from population surveys. BMJ 2000;321:343-5.

12 Walker A, O'Brien M, Traynor J, Fox K, Goddard E, Foster K. Living in Britain: results from the 2001 general household survey. London: Stationery Office, 2002.

13 Sandler DP, Comstock GW, Helsing KJ, Shore DL. Deaths from all causes in non-smokers who lived with smokers. Am J Public Health 1989;79:163-7.

14 Hole DJ, Gillis CR, Chopra C, Hawthorne VM. Passive smoking and cardiorespiratory health in a general population in the west of Scotland. BMJ $1989 \cdot 299 \cdot 423-7$

(Accepted 6 May 2004)

doi $10.1136 /$ bmj.38146.427188.55

\title{
Acquisition of Helicobacter pylori infection after outbreaks of gastroenteritis: prospective cohort survey in institutionalised young people
}

Rémi Laporte, Philippe Pernes, Pascale Pronni, Frédéric Gottrand, Pascal Vincent

Inserm

E9919-Universite

de Lille II JE 2225,

Institut de Biologie

de Lille, France

Rémi Laporte

resident in paediatrics

Pascal Vincent

microbiologist

Centre Antoine de

Saint-Exupéry,

Vendin-le-Vieil,

France

Philippe Pernes

paediatrician

Pascale Pronnier

paediatrician

Clinique de

Pédiatrie, Hôpital

Jeanne de Flandre,

Lille, France

Frédéric Gottrand

professor

Correspondence to:

P Vincent,

Laboratoire de

Bactériologie-Hygiène,

Centre Hospitalier

Régional et

Universitaire,

Hôpital Calmette

1 Boulevard J

Leclercq, 59037

Lille Cedex, France

p-vincent@chru-lille.fr

BMJ 2004;329:204-5
The exact mode of spread of Helicobacter pylori is still unknown. Transmission during transit disorders of the gastrointestinal tract has been suggested, although there is no evidence to date of transmission during outbreaks of gastroenteritis. ${ }^{1-3}$ We determined whether gastroenteritis in young people infected with $H$ pylori can lead to acquisition of the bacterium by peers.

\section{Participants, methods, and results}

Our study took place in a French institution for neurologically handicapped children and adolescents. The young people had been institutionalised for several years and resided across five housing sections (A to E). We included all 112 residents in May 2001. H pylori infection present at the outset of the study was

- Person days of infective diarrhoea per week

- - - Diarrhoea outbreak level limit (95\% limit Poisson distribution)

』 Person days of infective vomitus per week

』ु Individual living in section $\mathrm{E}$

§ Individual living in another section but in close contact with

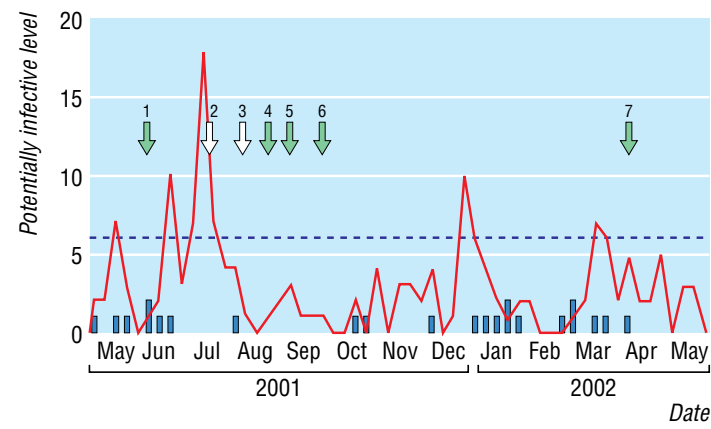

Relation between new cases of Helicobacter pylori infection and exposure to infective diarrhoea and vomitus in housing section $\mathrm{E}$ detected by using the non-invasive HpSA stool antigen test (Meridian; 91\% sensitivity and 93\% specificity). ${ }^{4}$ Stool samples were stored and transported at $4^{\circ} \mathrm{C}$ within 48 hours and then frozen. The residents were monitored for one year. Events and clinical data were recorded daily by nurses. Gastroenteritis was defined as a sudden outbreak of liquid stools in more than two residents concurrently. For each patient with $H$ pylori infection, we defined one day of potentially infective diarrhoea or vomiting as that when at least one liquid stool or vomitus was emitted. Stool samples were collected every week for each resident who was free of infection at the study outset, and at the end of the study we compared the last sample with the first sample. When conversion was observed, we identified the oldest positive stool sample collected from that patient during follow up.

The prevalence of $H$ pylori infection was high; 47 of the 112 residents (42\%) were positive for $\mathrm{H}$ pylori at the study outset. Seven of the 65 residents who were initially negative for $H$ pylori showed conversion during follow up (figure). Five of the seven young people lived in section $\mathrm{E}$, and our records showed that the two other residents had frequent contacts with the infected patients from section $\mathrm{E}$ during physiotherapy and entertainment sessions. Vomitus was rare in all sections. The frequency of diarrhoeal stools from the infected patients varied across sections; residents of sections A and B had 475 and 338 person days of potentially infective diarrhoea over the year, respectively. Acute diarrhoea was rare in these sections, and no outbreaks of gastroenteritis were recorded. A lower frequency of diarrhoeal stools was observed in sections $\mathrm{C}, \mathrm{D}$, and $\mathrm{E} ; 34,104$, and 164 person days of potentially infective diarrhoea over the year, respectively. The frequency was always low in sections $\mathrm{C}$ and $\mathrm{D}$, where no outbreaks of gastroenteritis were 


\section{What is already known on this topic}

Diarrhoeal stools and vomitus from infected young people can contain viable Helicobacter pylori

\section{What this study adds}

New cases of $H$ pylori infection can occur in cohabiting young people after acute diarrhoea or vomitus in infected peers

observed, whereas in section E, four peaks of potentially infective diarrhoea occurred during outbreaks of gastroenteritis (figure). In all cases, conversion occurred three to 11 weeks after a peak of potentially infective diarrhoea.

\section{Comment}

An association was found between gastroenteritis and subsequent acquisition of $H$ pylor $i$ infection in cohabiting young people. Despite the limitations of the non-invasive test used to determine the presence of $H$ pylori, time and space clustering shows that conversions were not observed by chance. This chronological link suggests that, under usual conditions of life, there might be a causal link between outbreaks of gastroenteritis and transmission of $H$ pylori. ${ }^{5}$
We thank Marie-Jeanne Capron, Christine Guillemant, and the nursing staff of Centre Antoine de Saint-Exupéry, Vendin-leVieil, for help during the study, Danielle Samaille, Institut Pasteur de Lille, for transport of samples, and M Simonet for critical reading of the manuscript.

Contributors: RL performed the literature search, data collection, and biological and epidemiological analysis and interpretation, and drafted the report. PV was the academic supervisor of RL. PV initiated the project, was responsible for funding and design, organised the collection of samples, helped interpret the results, and wrote and revised the report; he will act as guarantor for the paper. $\mathrm{PhP}$ and $\mathrm{PP}$ were responsible for the care of the patients and management of the institution. FG was involved in the design of the study and advised on medical issues and discrepancies during the study. All authors critically analysed the data and wrote the paper.

Funding: RL received a scholarship from Laboratoire Gallia. Competing interests: None declared.

Ethical approval: This study was approved by the local ethics committee, Vendin-le-Vieil.

1 Thomas JE, Gibson GR, Darboe MK, Dale A, Weaver LT. Isolation of Helicobacter pylori from human faeces. Lancet 1992;340:1194-5.

2 Parsonnet J, Shmuely H, Haggerty T. Fecal and oral shedding of Helicobacter pylori from healthy infected adults. JAMA 1999;282:2240-5.

3 Leung WK, Siu KL, Kwok CK, Chan SY, Sung R, Sung JJ. Isolation of Helicobacter pylori from vomitus in children and its implication in gastro-oral transmission. Am J Gastroenterol 1999;94:2881-4.

Gisbert JP, Pajares JM. Diagnosis of Helicobacter pylori infection by stool Gisert JP Pas antigen deternion. a systematic

5 Hill AB. The environment and disease: association and causation. Proc $R$ Soc Med 1965;58:295-300.

(Accepted 16 April 2004)
Uveitis and iritis are rare adverse effects of prostaglandin F2 $\alpha$ analogues ${ }^{1}$ and are most common with latanoprost. ${ }^{2}$ A 77 year old woman with no previous history of iritis started travoprost eye drops in November 2002 for advanced pseudoexfoliation glaucoma and cataract in both eyes. Two months later, owing to inadequate control of ocular pressure, she had phacotrabeculectomy in the right eye; she had stopped the travoprost the night before. A week later she complained of swelling and discomfort in the operated eye. We advised her to use her topical steroid more often. The eye settled down and pressure stabilised. In August 2003 she had phacotrabeculectomy in her left eye and again stopped travoprost. As intraocular pressure was still high two weeks later, she restarted taking travoprost. After three weeks she had severe iritis (3+ cells and flare) and corneal oedema and began to take timolol. However, intraocular pressure rose again and she chose to restart travoprost. Five days later acute iritis developed in the left eye, which resolved only after stopping travoprost and starting a combination of a $\beta$ blocker and dorzolamide eyedrops to control the intraocular pressure. The patient's other drugs included bendrofluazide, diltiazem, ramipril, doxazosin, and chlordiazepoxide.

The close temporal association between starting travoprost and the onset of iritis, and recurrence after rechallenge suggests an adverse reaction to travoprost, scoring eight with the Naranjo algorithm. ${ }^{3}$ In the only reported case of iritis associated with travoprost, ${ }^{4}$ the patient was not rechallenged with the drug. The manufacturers of travoprost and the Medicines and Healthcare Products Regulatory Agency are aware of only one other case of uveitis associated with travoprost in the United Kingdom. Similar to patients who had adverse reactions to latanaprost, this woman developed iritis after incisional surgery. ${ }^{5}$

\section{Funding: None.}

Competing interests: SPD has received partial reimbursement of travel expenses for attending sponsored symposia organized by various drug companies including Pfizer; Alcon; Allergan; and Merck, Sharp, and Dohme.

1 British Medical Association, Royal Pharmaceutical Society of Great Britain. British national formulary. London: BMA, RPS, 2003: 515 (No 46.)

2 Warwar RE, Bullock JD, Ballal D. Cystoid macular edema and anterior uveitis associated with latanoprost use: experience and incidence in a retrospective review of 94 patients. Ophthalmology 1998;105:263-8.

3 Naranjo CA, Busto U, Sellers EM, Sandor P, Ruiz I, Roberts EA, et al. A method for estimating the probability of adverse drug reactions. Clin Pharmacol Ther 1981:30:239-45.

4 Faulkner WJ, Burk SE. Acute anterior uveitis and corneal edema associated with travoprost. Arch Ophthalmol 2003;121:1054-5.

5 Fechtner RD, Khouri AS, Zimmerman TJ, Bullock J, Feldman R, Kulkarni P, et al. Anterior uveitis associated with latanoprost. Am J Ophthalmol 1998;126:37-41.

(Accepted 2 March 2004)
Department of Ophthalmology, Doncaster Royal Infirmary,

Doncaster DN2 5LT

Manjula

Kumarasamy staff grade ophthalmologist

Shrivatsa P Desai consultant ophthalmologist

Correspondence to: S P Desai desaisp@hotmail.com

BMJ 2004;329:205 